\title{
Mobile application for the teaching of the International Classification for Nursing Practice
}

\author{
Aplicativo móvel para ensino da Classificação Internacional para a Prática de Enfermagem \\ Aplicación móvil para enseñar la Clasificación Internacional en la Práctica de Enfermería
}

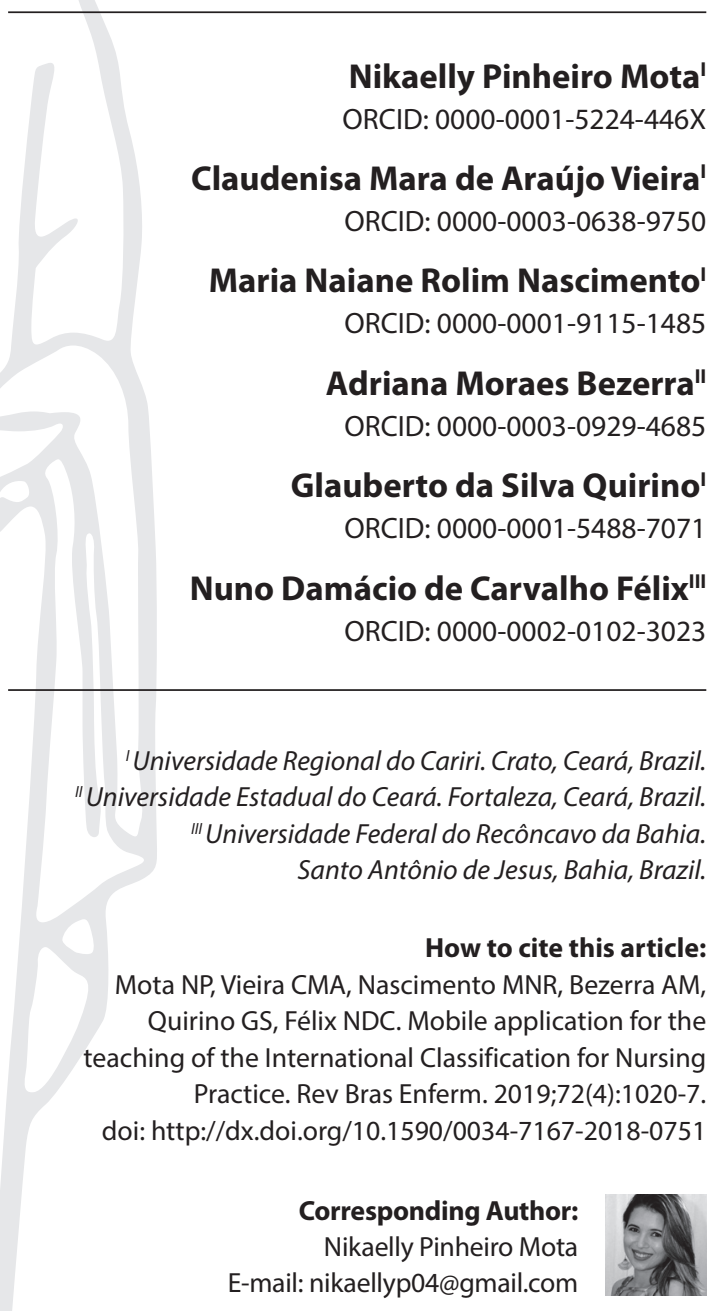

Submission: 09-19-2018 Aprovação: 10-20-2018

\begin{abstract}
Objective: Developing a mobile application for the teaching of the International Classification for Nursing Practice. Methods: Methodological applied research for technological production, performed in three phases of the contextualized instructional design model: analysis, design and development. Results: The application has an initial screen, which provides information about the team and its purpose. Then, four moblets are listed, including presentation, user's guide consisting of five modules, educational games and five clinical cases. The references on which the application was based are also presented. Final considerations: It was possible to develop an application with the potential to promote the knowledge of nursing students and professionals about this classification system.
\end{abstract}

Descriptors: Nursing; Educational Technology; Nursing Informatics; Standardized Nursing Terminology; Nursing Process.

\section{RESUMO}

Objetivo: Desenvolver um aplicativo móvel para o ensino da Classificação Internacional para a Prática de Enfermagem. Métodos: Estudo metodológico aplicado, de produção tecnológica, realizado em três fases do modelo de design instrucional contextualizado: análise, design e desenvolvimento. Resultados: $\mathrm{O}$ aplicativo possui uma tela inicial, na qual são fornecidas informações sobre a equipe e o tópico de ajuda. Em seguida, são listados quatro moblets, que versam sobre apresentação, guia do usuário constituído por cinco módulos, jogos educativos e cinco casos clínicos. Também são dispostas as referências utilizadas para a construção do aplicativo. Considerações finais: Foi possível desenvolver o aplicativo com potencial para impulsionar estudantes e profissionais de enfermagem a ter um melhor conhecimento sobre o referido sistema de classificação. Descritores: Enfermagem; Tecnologia Educacional; Informática em Enfermagem; Terminologia Padronizada em Enfermagem; Processo de Enfermagem.

\section{RESUMEN}

Objetivo: Desarrollar una aplicación móvil para enseñar la Clasificación Internacional en la Práctica de Enfermería. Métodos: Estudio metodológico aplicado, de elaboración tecnológica, realizado en tres fases del modelo de diseño instructivo contextualizado: análisis, diseño y desarrollo. Resultados: La aplicación tiene una pantalla de bienvenida, en que brinda información sobre el personal y el tema de auxilio. A continuación, se enumeran cuatro moblets, que versan sobre la presentación, el guía del usuario constituido por cinco módulos, juegos educativos y cinco casos clínicos. También se encuentran las referencias utilizadas en la elaboración de la aplicación. Consideraciones finales: Fue posible desarrollar la aplicación con potencial para impulsar a estudiantes y a profesionales de enfermería que conozcan mejor dicho sistema de clasificación.

Descriptores: Enfermería; Tecnología Educacional; Informática Aplicada a la Enfermería; Terminología Normalizada de Enfermería; Proceso de Enfermería. 


\section{INTRODUCTION}

The teaching-learning process is characterized, in contemporary times, by dynamism, modernization and the use of technological tools, to make it more attractive and participatory, with potential for the meaningful acquisition of knowledge. In this universe, and for this purpose, it is necessary to stimulate and promote the use of innovative approaches, such as multimedia teaching programs and tools, centered on the apprentice and aligned to the context and the needs of the target audience. Thus, these approaches become essential technological strategies in the consolidation of a flexible teaching process that promotes active learning ${ }^{(1-2)}$.

The use of information and communication technologies can strengthen the teaching-learning process by encouraging the learner's autonomy, the joint construction of knowledge, and the dynamism derived from computerization, stimulating the formation of concepts and the development of skills in various areas of education ${ }^{(3)}$, nursing being one of them. These technologies need to be incorporated into educational systems, with the prospect of providing a more consistent learning process, since the traditional teaching model has weaknesses with regard to the subjects' active acquisition of knowledge ${ }^{(1)}$.

The development and adoption of these technologies, such as applications, social networks and virtual learning environments, support the learning of concepts that are essential for health and nursing practice. They are innovative instruments, capable of making the teaching-learning process more attractive and dynamic ${ }^{(4)}$, and that can generate potential changes also in health care services, in relation to the quality of the care provided to the population, because they stimulate the development of knowledge and skills that strengthen the professionals' practice, promoting the reduction in the risk of human error ${ }^{(5)}$.

The use of educational and communication technologies has grown exponentially in nurse education, especially when related to the simulation of virtual users and clinical cases $^{(6)}$, the systematization of nursing care $^{(7)}$ and the use of classification systems ${ }^{(8)}$, meeting the demand for the use of instruments built with a scientific basis, using a standardized language and supported by the nursing theories.

When it comes to standardized language, studies $^{(9-10)}$ show the prevalence of the use of classification systems such as NANDA International, the Nursing Interventions Classification (NIC) and the Nursing Outcome Classification (NOC) when compared to the International Classification for Nursing Practice (ICNP'), even though this is the only nursing classification system recognized by the World Health Organization (WHO) that is inserted in the family of international classifications as related classification ${ }^{(11)}$.

The parsimony in relation to the use of ICNP ${ }^{\circ}$ in the practical field may be related to its lack of dissemination in the academic sphere, contributing to the neglect of the development of skills in the use of this terminology in the professionals' training ${ }^{(12)}$, which can be facilitated with the use of a mobile application that promotes the knowledge of its procedures, allowing difficulties about the classification systems to be more readily remedied ${ }^{(13)}$.

ICNP's contribution to the consolidation of nursing as a science should be emphasized, since it groups together standardized and relevant terms that characterize nursing care within a multi-professional context, helping nurses identify problems. In this context, clinical reasoning is required for the decision-making involved in the solution to these problems, and for establishing the necessary interventions, where the professional acts as protagonist of the care process ${ }^{(14)}$. Therefore, the use of ICNP ${ }^{\circ}$ in the teaching-learning process can happen consistently, promoting meaningful learning, both for students and professionals ${ }^{(15)}$.

This study is grounded on the development of a multimedia resource, namely, an application for mobile devices, with the purpose of providing an innovative tool to users, that is easy to access and transport, to clear doubts and awaken the interest and motivation for knowledge, especially since it relates to a classification system that is also a nursing care technology to be exploited.

\section{OBJECTIVE}

Developing a mobile application for the teaching of the International Classification for Nursing Practice.

\section{METHODS}

\section{Ethical aspects}

This study was not submitted to the Research Ethics Committee, seeing as it used the literature as its sole database, with no involvement of human beings. It was registered in the International Council of Nurses (ICN) for the non-commercial use of ICNP'.

\section{Theoretical-methodological framework: International Classification for Nursing Practice}

ICNP ${ }^{\circ}$ was approved by ICN in 1989, its first version dating from 1996 , having configured itself as a nursing classification system in continuous process of development, which groups together relevant terms for the structuring of diagnoses, outcomes and nursing interventions. It is a standardized terminology, extensive and complex, which represents the field of nursing practice in a global context, seeking to introduce accuracy and standardization in nursing actions, upon registration of the activities. On the other hand, it is developed as information technology for providing the collection, storage and analysis of nursing data in a variety of scenarios, languages and geographical regions, contributing to the effectiveness of the practice of nursing professionals and, above all, allowing this practice to become visible and recognized, in the context of health and society. Currently, the classification's 2017 version features 4,326 terms distributed among 10 organizing concepts within the Seven-Axes Model; 1,915 pre-condemned concepts (relating to nursing diagnoses, outcomes and interventions); and 2,401 primitive concepts ${ }^{(16-17)}$, considering ISO Standard 18,104(18).

To support its progress and overcome challenges, ICN initiated, in 2003, the accreditation of centers for research and development of ICNP ${ }^{\circ}{ }^{(19)}$. Today, there are 15 ICNP $^{\circ}$ centers around the world ${ }^{(20)}$, which contribute to the development of the classification in a global context, as well as to that of its terminological subsets.

In Brazil, the Center for Research and Development of ICNP', located in João Pessoa (PB), contributes to the classification's development from the construction and validation of its terminological 
subsets, based on dissertations and theses ${ }^{(21)}$, with the publication of articles in national and international journals, which promote the dissemination of knowledge about it and support nursing practice, teaching and research. This set of data was used in the design, analysis and development of this study.

\section{Contextualized instructional design model}

We opted for this model because of its simplicity, clarity and cohesion in relation to the objective proposed, in addition to its extensive use in the field of construction of mobile nursing applications. It consists of five phases and has well-defined actions: analysis, design, development, implementation and evaluation ${ }^{(22)}$.

The analysis phase consists of seizing the problem and devising a related solution, from the survey of the needs and characteristics of the target audience, the collection of data from the literature, the definition of the educational objectives and contents, the analysis of the technological infrastructure and the creation of a diagram to guide the construction of the tool. The design phase focuses on the pedagogical concept that promotes learning, involving the planning and production of educational content; the definition of the topics and writing of the modules; the selection of media; and the layout of the interface. The development phase comprises the selection of the multimedia application's tools, the definition of its navigation structure and the planning of the configuration of its environments. The implementation phase covers the configuration of the technological tools and resources, as well as the creation of an environment for download of the application on the internet and its use on mobile devices by the target audience. The evaluation phase involves the analysis of experts in relation to the application's contents, didactic resources and interface ${ }^{(22)}$.

\section{Type of study}

This is a methodological applied research for the technological production of a mobile application addressing ICNP', based on the information and communication technologies. In this study, we chose to use the phases of analysis, design and development of the contextualized instructional design model.

\section{Methodological procedures}

The analysis phase considered the educational issue involving the lack of use of ICNP ${ }^{\circ}$ in health care practice due to the limitation of knowledge about the classification system, in addition to the nursing staff's resistance to work with clinical reasoning methods, due to work overload ${ }^{(23-24)}$. The development of a mobile application for the classification system's teaching may contribute to its practical application, since it is adaptable to the availability of nursing students, professionals and other interested parties, while target audience of this study.

The collection of data from the literature for this phase involved the choice of the model for the application's development and subsequent search for articles, dissertations, theses and books, to evaluate the real need or demand for strategies of approach to the subject, as well as the scope of the objective proposed in this study. The descriptors "Nursing Process" and "Nursing" and the keyword "International Classification for Nursing Practice", all in Portuguese, were used in the Scientific Electronic Library Online (SciELO), the Latin American and Caribbean Center on Health Sciences Information (LILACS), the Sucupira platform and the bank of thesis of Coordenação de Aperfeiçoamento de Pessoal de Nível Superior (Capes); also, the versions published in INCP's books were surveyed, with emphasis on the 2015 version, subsidizing the development of the application's contents. This step took place between August 2016 and May 2017, during which the contents to be used, the objectives of the system, its technological infrastructure, the potential for environmental studies and the creation of the diagram for the software's development were defined.

The application's design was initially conceived by the authors, so that the data collected in the previous phase could be organized to conform to the purpose of this work. The potentialities and limitations in the software's development were considered, such as issues involving the time required and the scarcity of human and financial resources for its implementation. The educational content, the topics and writing of the previously arranged data, the selection of the media and the initial layout were defined.

In the development phase, the implementation of the framework that had been previously developed and the application's configuration by a programmer in the field of computer science occurred. It should be noted that the language of the digital material was as clear and objective as possible, to facilitate the teaching-learning process. In this study, with the proposal to develop a software that is both accessible and free, the Android operating system was chosen, and it was named CIPE Play (CIPE stands for INCP in Portuguese.)

\section{Data analysis}

The results of this study's phases were organized in a descriptive manner in tables and figures to clarify them and facilitate the analysis of the data obtained, as well as its correlation with the state of the art produced both nationally and internationally.

\section{RESULTS}

The phases of analysis, design and development were fundamental for the achievement of this study's objective. The mobile application developed was titled CIPE Play and was made available for download on the Android system, free of charge, on the Google Play e-shop. The choice for the Android operating system was due to it being compatible with most mobile devices (phones and tablets), making it an accessible application with a greater number of users. Users require internet access to download it and, after saving it on the device's memory, the application becomes available also for offline use.

Moblets that facilitate the user's interactivity with the application were developed, each of them with modules for better explanation. It was composed of 14 screens, namely: initial screen (home, help, about, exit); presentation; five user's guides; two educational games; and references, as described in Chart 1.

With regard to the first screen, users have access to relevant information about the authors of this study and, in case they have any questions in relation to the software, they may choose 
the "help" option, which shows the navigation flowchart, along with the options "start" and "exit". On the next screen, there are four options for the user to select. The first is the software's presentation; the second is the "user's guide", "educational games" and "references" screens, as shown in Figure 1.

The moblet "user's guide" consists of five modules relating to key information about the SNC, the NP and their classification systems. In this screen, the user finds a graphical representation of a nurse explaining, in speech bubbles, the main information associated with the theme; in the context of INCP, the year it was organized, those responsible for its development and its main advantages are presented; and INCP's versions, with a timeline explaining each version developed (Figure 2).

The user clicks on the version chosen and receives all the information about it; explanations on the development of the wording used in nursing diagnoses, outcomes and interventions, according to ISO Standard 18,104 and INCP's Seven-Axis Model; and finally, a module showing INCP's main Terminological Subsets, addressing the concept and its purpose (Figure 3).

When clicking a particular option, users are granted access to up-do-date articles, dissertations and theses discussing the wording used in nursing diagnoses, outcomes and interventions, pre-developed for particular areas of nursing care. "Educational games" is the following moblet, consisting of clinical cases and a quiz. Finally, there is a moblet with the references used in the software's construction (Figure 4).

The first option includes five clinical cases, where users may select what they want to access, because there are different cases for specific priority areas of nursing. The user must identify the signs, symptoms and human responses, according to the clinical case presented, and then select the option with the main nursing diagnoses, outcomes and interventions based on INCP. Users can view all resolutions of these cases by clicking on the option "view answers." Finally, there is a quiz to evaluate their knowledge about the subject.

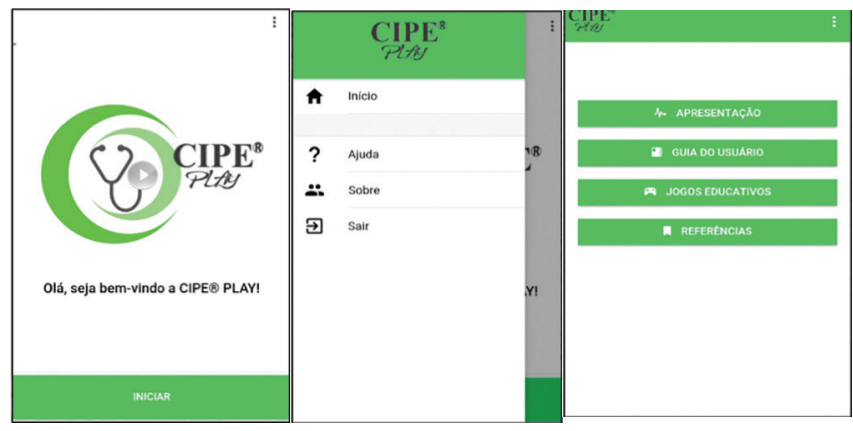

Source: CIPE' Play.

Figure 1 - CIPE Play's presentation screens, Crato, Ceará, Brazil, 2019

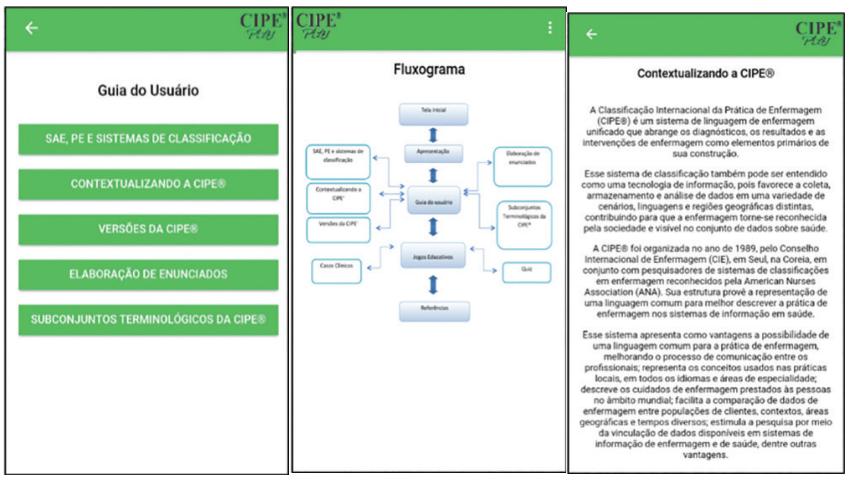

Source: CIPE Play.

Figure 2 - User's guide and CIPE Play's presentation and contextualization flowchart, Crato, Ceará, Brazil, 2019

Chart 1 - Descriptive synthesis of the screens that composed CIPE Play, Crato, Ceará, Brazil, 2019

\begin{tabular}{|c|c|l|}
\hline \multirow{2}{*}{ Main screens } & Components & \multicolumn{1}{c|}{ Objectives } \\
\cline { 2 - 3 } & Start & Returning to home screen \\
\cline { 2 - 3 } & Help & Schematizing the application using a flowchart \\
\cline { 2 - 3 } & Exit & Providing information about the team responsible for the software's development \\
\cline { 2 - 3 } & Presentation & Closing the application \\
\cline { 2 - 3 } & User's Guide & Welcoming the user and explaining the purpose of the application \\
\hline User's Guide Topic I & SNC ${ }^{*}$ NP ${ }^{* *}$ and classification systems & Synthesizing the concepts using illustrative images \\
\hline User's Guide Topic II & Contextualizing INCP & Conceptualizing INCP \\
\hline User's Guide Topic III & INCP's Versions & Addressing ICNP's versions using a timeline \\
\hline \multirow{2}{*}{ User's Guide Topic IV } & Wording & $\begin{array}{l}\text { Explaining how to write a diagnosis, an outcome and an intervention, based on ISO } \\
\text { Standard 18,104 and on INCP's Seven-Axis Model }\end{array}$ \\
\hline User's Guide Topic V & INCP's terminological subsets & $\begin{array}{l}\text { Explaining the concept of INCP's terminological subsets and offering scientific studies } \\
\text { that use the subsets for each clinical practice }\end{array}$ \\
\hline Educational Games Topic I & Clinical cases & Reviewing the contents based on five clinical situations \\
\hline Educational Games Topic II & Quiz & Reviewing the contents based on nine questions \\
\hline & References & Informing the references used \\
\hline
\end{tabular}




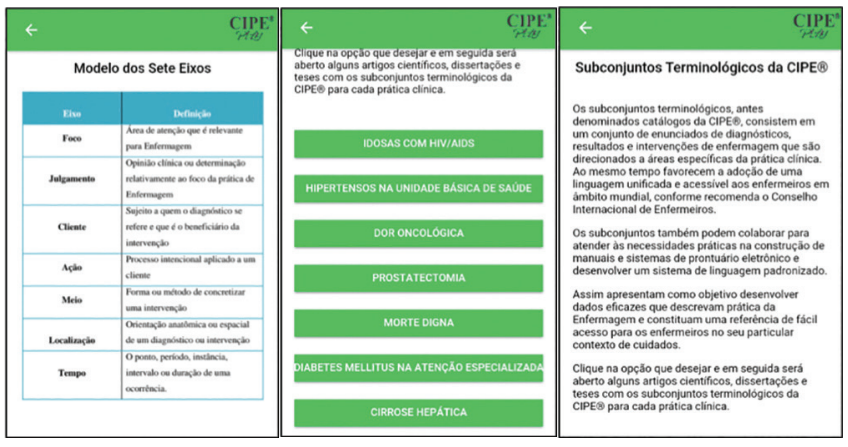

Source: CIPE" Play.

Figure 3 - Seven-Axis Model and INCP's Terminological Subsets, Crato, Ceará, Brazil, 2019

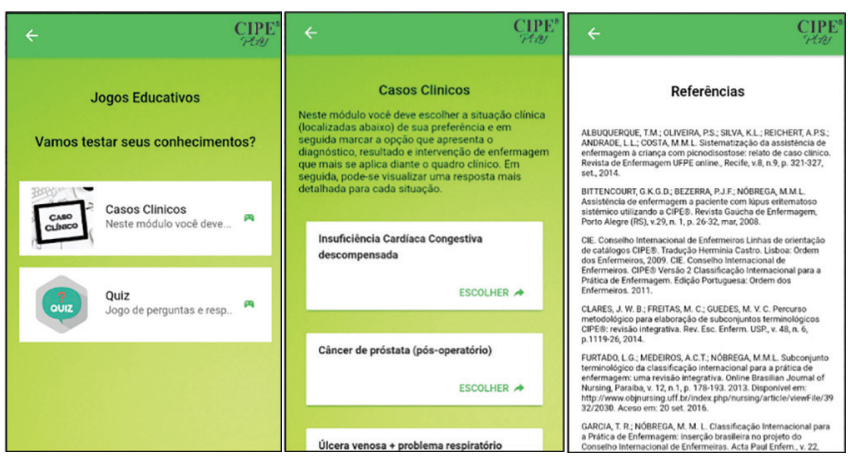

Source: CIPE" Play.

Figure 4 - Educational games, clinical cases and references, Crato, Ceará, Brazil, 2019

\section{DISCUSSION}

The software called CIPE Play is a technology that aims to facilitate the teaching-learning process, both for nursing professionals and students, in relation to the use of INCP. In this context, the use of these technological resources has increased as fast as their development, producing a generation of professionals who use these technologies to support their decision-making (25-26). This kind of technological resource aims to assign dynamism to education, and enable the development of skills and knowledge that are capable of subsidizing the resolution of problems.

Authors have developed mobile educational applications using INCP, with varying objectives, such as bedside care in intensive care units ${ }^{(27)}$ and another to support decision-making in the nursing care of children and adolescents ${ }^{(3)}$. However, these studies were conducted for the teaching of clinical specificities of nursing, not presenting general data about the classification system, thus indicating a gap in technological knowledge and development, associated with the need for greater dissemination of specific knowledge about the system.

These tools may have different objectives, such as clinical aid, improving the care provided to the users of health services and promoting improvements in communication ${ }^{(25)}$. In this study, it was sought, with the application developed, to focus on issues related to attractiveness and objectivity, so that some aspects, such as the choice and the size of the fonts, the colors of the design and the contents would generate greater visual comfort and dynamism of the information.
The use of mobile technology in healthcare may offer several benefits. It has been revolutionizing and being accepted among professionals of this area ${ }^{(28)}$. The rapid evolution of informational technologies promotes changes in the way of understanding contents and promotes the construction of knowledge, becoming an active educational tool. Thus, it is possible to note that teaching strategies based on active methods promote the articulation between theory and practice, both in undergraduate courses and for the continuous training of nursing professionals ${ }^{(29)}$.

The use of active methodologies while pedagogical teaching tools in undergraduate courses in nursing has been favoring the teaching-learning process, enabling students to experience clinical practice early on by searching for the solution to common health problems; addressing the various needs related to the completeness of care; and being unique instruments for the development of these professionals' skills and competence ${ }^{(26)}$.

In this sense, it should be reinforced that, for a software to be successful, the information provided by it needs to be attractive. In this way, visual representations allow users to understand the information better and recall it more easily, from its association with images ${ }^{(30)}$.

Furthermore, a research conducted in a university in Spain, with the participation of 109 nursing students, noted that the use of educational technologies is highly suitable for these students due to their attractiveness, supporting the development of plans of care and diagnoses. The main implication of the tool was related to the Nursing Process' applicability, as its use promotes the knowledge and understanding of taxonomies, as well as the efficiency of the care provided by nurses, being very useful in clinical practice ${ }^{(13)}$.

With regard to the educational games, like the quiz and clinical cases, they are tools that facilitate the learning process and are very flexible in the educational environment. This is mainly due to their motivational character, which highlights the importance of the software's development ${ }^{(31)}$.

These games are characterized as a teaching strategy and are intended to assist the training of nurses on diagnostic reasoning, consequently facilitating its use in clinical practice. Their advantage is mainly due to their approach being based on questions, not answers, stimulating the active participation of apprentices in the teachinglearning process, as well as their interest, critical thinking, reflection, learning from experience, argumentation, and the articulation between theory and practice ${ }^{(29)}$. In addition, testing their reasoning with games provides the students a safe environment for them to make clinical decisions without the risk of damaging a real user ${ }^{(6)}$. In this context, the students' access to the contents may take place in the form of a detailed presentation and exercises problematizing the issue, challenging their curiosity and proposing digital simulations of clinical cases before they are faced with real ones.

This kind of software, as well as other information and communication technologies, promote some of the students' qualities, such as, for example, their autonomy, their time flexibility for studying, and the pace of their learning and self-organization ${ }^{(30)}$. The application developed in this study opens doors to the belief that its use contributes to the teaching-learning process, promoting the protagonism of the target audience and supporting the clinical decision-making of nurses.

Dynamic, interactive and innovative strategies need to be implemented in nurse education, especially in relation to INCP, 
so that nursing can advance as a science, and also to promote the improvement in learning methods, it being of utmost importance that the memorization of certain issues is reduced, giving way to reflection and decision-making, based on clinical findings.

It should also be noted that the terminology subsets present in the application have the purpose of clarifying the classification system's understanding, not being limited to them, and arousing the interest of nurses. Thus, other subsets can be searched for in the literature, according to the customers and/or health priorities of each work sector. The elucidation of this application, while research tool, can encourage the use of this and other technological tools by nurses, as well as encourage the interest in the development of new technologies aligned to the field's theoretical-practical knowledge, and promote improvements in the quality of care ${ }^{(32-33)}$.

\section{Study limitations}

This study's limitations include the application having been developed on the Android platform, making it necessary that this technology is adapted to other operating systems, and the use of three phases of the contextualized instructional design model. The need for completion of the phases of implementation and evaluation is necessary to verify the application's suitability and offer improvements, this being a proposal for subsequent studies.

\section{Contributions to the field of nursing, health, or public policies}

This study envisions benefits such as the ability to expand the information on this classification system, both for undergraduate students and for professionals in the labor market, facilitating the process of communication between nurses by promoting a unified language, as well as the use of the contents described in the software in clinical practice, regardless of the user's culture or geographical region. In addition, these technologies may be inserted in the teaching-learning process, in the context of nursing and its classification systems, particularly INCP in this study.

This results in the dissemination of a unified language, since the development and the use of a classification system contribute directly to this purpose. The research highlights the importance of the usability of this digital resource in health care and academic contexts, to promote clinical judgment and decision-making.

\section{FINAL CONSIDERATIONS}

The development of this application allowed the construction of an informational technology for the teaching of INCP. This tool has the potential to promote the understanding of students and nursing professionals about INCP and its use in professional nursing practice. Furthermore, it is able to disseminate knowledge in any formal geographical sphere. In the future, we intend to carry out, as this study's next step, the validation of the software's contents, appearance and applicability, with judges from the fields of nursing and computer technology, to ensure a more adequate and reliable technology to the academic and professional community.

\section{FUNDING}

Fundação Cearense de Apoio ao Desenvolvimento Científico e Tecnológico (Funcap).

\section{REFERENCES}

1. Salvador PTCO, Mariz CMS, Vítor AF, Ferreira Jr MA, Fernandes MID, Martins JCA, et al. Validation of virtual learning object to support the teaching of nursing care systematization. Rev Bras Enferm [Internet]. 2018 [cited 2018 Sep 13];71(1):16-24. Available from: http://dx.doi. org/10.1590/0034-7167-2016-0537

2. Silva DML, Carreiro FA, Mello R. Educational technologies in nursing assistance in health education: integrating review. Rev Enferm UFPE[Internet]. 2017 [cited 2018 Mar 6];11(Suppl. 2):1044-51. Available from: https://periodicos.ufpe.br/revistas/revistaenfermagem/article/ view/13475

3. Silva KL, Evora YD, Cintra CS. Software development to support decision making in the selection of nursing diagnoses and interventions for children and adolescents. Rev Latino-Am Enfermagem [Internet]. 2015 [cited 2018 Sep 13];23(5):927-35. Available from: http://dx.doi. org/10.1590/0104-1169.0302.2633

4. Pereira FG, Silva DV, Sousa LM, Frota NM. Building a digital application for teaching vital signs. Rev Gaúcha Enferm [Internet]. 2016 [cited 2018 Sep 13];37(2):e59015. Available from: http://www.scielo.br/pdf/rgenf/v37n2/en_0102-6933-rgenf-1983-144720160259015.pdf

5. Barra DCC, Dal Sasso GTM, Almeida SRW. Usability of computerized nursing process from the ICNP ${ }^{\oplus}$ in intensive care units. Rev EsC Enferm USP [Internet]. 2014 [cited 2018 Sep 13];49(2):326-34. Available from: http://www.scielo.br/pdf/reeusp/v49n2/0080-6234reeusp-49-02-0326.pdf

6. Millão LF, Vieira TW, Santos ND, Silva APSS, Flores CD. Integration of digital technologies in nursing teaching: simulation of a clinical case about pressure ulcers with the SIACC software. Reciis [Internet]. 2017 [cited 2018 Sep 13];11(1):1-12. Available from: http://www.brapci.inf. $\mathrm{br} / \mathrm{v} / \mathrm{a} / 23038$

7. Rezende LCM, Santos SR, Medeiros AL. Assessment of a prototype for the Systemization of Nursing Care on a mobile device. Rev Latino-Am Enfermagem [Internet]. 2016 [cited 2018 Sep 13];24:e2714. Available from: http://www.scielo.br/pdf/rlae/v24/0104-1 169-rlae-24-02714.pdf

8. Lima JJ, Vieira LGD, Nunes MM. Computerized nursing process: development of a mobile technology for use with neonates. Rev Bras Enferm [Internet]. 2018 [cited 2018 Sep 13];71(Suppl-3):1273-80. Available from: http://www.scielo.br/pdf/reben/v71s3/0034-7167-reben71-s3-1273.pdf 
9. Furuya RK, Nakamura FRY, Gastaldi ABG, Rossi LA. Nursing classification systems and their application in care: an integrative literature review. Rev Gaúcha Enferm [Internet]. 2011 [cited 2018 Sep 13];32(1):167-75. Available from: http://dx.doi.org/10.1590/ S1983-14472011000100022

10. Morais SCRV, Nóbrega MML, Carvalho EC. Convergence, divergence and diagnostic accuracy in the light of two nursing terminologies. Rev Bras Enferm [Internet]. 2015 [cited 2018 Sep 13];68(6):777-83. Available from: http://dx.doi.org/10.1590/0034-7167.2015680613i

11. International Council of Nurses (ICN). International perspectives. Int Nurs Rev [Internet]. 2009 [cited 2018 Sep 13];56(2):155-6. Available from: https://doi.org/10.1111/j.1466-7657.2009.00731_2.x

12. Bitencourt GR, Oliveira FM, Santana RF, Marques D, Rocha ICM, Cavalcanti ACD. [Knowledge and practices of nursing students on nursing classification systems]. Recom [Internet]. 2016 [cited 2018 Sep 13];6(2):2247-57 Available from: http://www.seer.ufsj.edu.br/index.php/ recom/article/view/969 Portuguese.

13. Ayllón FS, Oliveira AC, Fernández MG, Martín JA, Moreno IM, Pérez PE. Assessment of the web tool nanda.es for nursing diagnoses by nursing students. REUFSM [Internet]. 2014 [cited 2018 Sep 13];4(2):276-83. Available from: https://periodicos.ufsm.br/reufsm/article/ view/10713/pdf

14. Félix NDC, Ramos NM, Nascimento MNR, Moreira TMM, Oliveira CJ. Nursing diagnoses from ICNP ${ }^{\oplus}$ for people with metabolic syndrome. Rev Bras Enferm [Internet]. 2018 [cited 2018 Sep 13];71 Suppl 1:467-74. Available from: http://dx.doi.org/10.1590/0034-7167-2017-0125

15. Avelino CCV, Costa LCS, Buchhorn SMM, Nogueira DA, Goyatá SLT. Teaching-learning evaluation on the ICNP ${ }^{\circledR}$ using virtual learning environment. Rev Bras Enferm [Internet]. 2017 [cited 2018 Sep 13];70(3):602-9. Available from: http://dx.doi. org/10.1590/0034-7167-2016-0545

16. International Council of Nurses (ICN) [Internet]. Geneva: International Classification for Nursing Practice (ICNP®). [updated 2018; cited 2018 Sep 13]. Available from: http://www.old.icn.ch/what-we-do/international-classification-for-nursing-practice-icnpr/

17. Garcia TR, Bartz CC, Coenen AM. CIPE : uma linguagem padronizada para a prática profissional. In: Garcia TR, organizer. Classificação Internacional para a Prática de Enfermagem (CIPE $\left.{ }^{\oplus}\right)$ : Versão 2017. Porto Alegre: Artmed; 2017. p. 1-16.

18. International Organization for Standardization. ISO 18104:2014: health informatics: categorial structures for representation of nursing diagnoses and nursing actions in terminological systems[Internet]. Geneva, 2014 [cited 2018 Sep 13]. Available from: https://www.iso.org/ standard/59431.html

19. International Council of Nurses (ICN) [Internet]. Geneva: International Council of Nurses (ICN) [cited 2018 Sep 13]. Available from: https:// www.icn.ch/?option=com_content\&ltemid=430\&catid=450\&id=867\&lang=es\&view=article

20. International Council of Nurses (ICN). ICN accredited centres for ICNP ${ }^{\circledR}$ research \& development. [Internet]. Genebra: ICN [cited 2018 Jan 13]. Available from: http://www.old.icn.ch/what-we-do/icn-accredited-centres-for-icnpr-research-a-development/

21. Carvalho CMG, Cubas MR, Nóbrega MML. Brazilian method for the development terminological subsets of ICNP®: limits and potentialities. Rev Bras Enferm [Internet]. 2017 [cited 2018 Sep 13];70(2):430-5. Available from: http://dx.doi.org/10.1590/0034-7167-2016-0308

22. Filatro A. Design instrucional contextualizado. 2a. ed. São Paulo: Senac; 2007.

23. Barra DCC, Dal Sasso GTM. The nursing process according to the international classification for nursing practice: an integrative review. Texto Contexto Enferm [Internet]. 2012 [cited 2018 Sep 13];21(2):440-7. Available from: http://www.scielo.br/pdf/tce/v21n2/en_a24v21n2.pdf

24. Silva EGC, Oliveira VC, Neves GBC, Guimarães TMR. [Nurses' knowledge about Nursing Care Systematization: from theory to practice]. Rev Esc Enferm USP [Internet]. 2011 [cited 2018 Sep 13];45(6):1380-6. Available from: http://www.scielo.br/pdf/reeusp/v45n6/en_v45n6a15.pdf Portuguese.

25. Souza JF, Gonçalves FB, Queiroz VAR, Queiroz RS. Evaluation of an application for aid raising a decision making critical patients. Rev Saúde Com [Internet]. 2015 [cited 2018 Sep 13];11(1):59-68. Available from: http://www.uesb.br/revista/rsc/v11/v11n1a07.pdf

26. Souza EFD, Silva AG, Silva AILF. Active methodologies for graduation in nursing: focus on the health care of older adults. Rev Bras Enferm [Internet]. 2018 [cited 2018 Sep 13];71(Suppl. 2):920-4. Available from: http://www.scielo.br/pdf/reben/v71s2/0034-7167-reben-71-s2-0920.pdf

27. Barra DCC, Dal Sasso GTM. Mobile bedside technology: computerized nursing processes in intensive care unit from ICNP® 1.0. Texto Contexto Enferm [Internet]. 2010 [cited 2018 Sep 13];19(1):54-63. Available from: http://www.scielo.br/pdf/tce/v19n1/v19n1a06.pdf

28. Tibes CM, Cherman EA, Souza VMA, Évora YDM, Zem-Mascarenhas SH. Image processing in mobile devices to classify pressure injuries. Rev Enferm UFPE [Internet]. 2016 [cited 2018 Sep 13];10(11):3840-7. Available from: https://periodicos.ufpe.br/revistas/revistaenfermagem/ article/view/11464

29. Góes FSN, Dalri MCB, Fonseca LMM, Canini SRMS, Scochi CGS. Developing clinical cases to reach diagnostic reasoning. Rev Eletr Enf [Internet]. 2014 [cited 2016 Apr 5];16(1):44-51. Available from: https://doi.org/10.5216/ree.v16i1.20564

30. Frota NM, Barros LM, Araújo TM, Caldini LN, Nascimento JC, Caetano JA. [Construction of an educational technology for teaching about nursing on peripheral venipuncture]. Rev Gaúcha Enferm [Internet]. 2013 [cited 2018 Sep 13];34(2):29-36. Available from: http://dx.doi. org/10.1590/S1983-4472013000200004 Portuguese.

31. Barbosa PA, Murarolli PL. Games and new technologies in education. Perspect Ciênc Tecnol [Internet]. 2013 [cited 2018 Sep 13];2(2):39-48. Available from: http://fatece.edu.br/arquivos/arquivos\%20revistas/perspectiva/volume2/3.pdf

32. Oliveira RM, Duarte AF, Alves D, Furegato ARF. Development of the TabacoQuest app for computerization of data collection on 
smoking in psychiatric nursing. Rev Latino-Am Enfermagem [Internet]. 2016 [cited 2018 Sep 13];24:e2726. Available from: http://dx.doi. org/10.1590/1518-8345.0661.2726

33. Vêscovi SJB, Primo CC, Sant' Anna HC, Bringuete MEO, Rohr RV, Prado TN, et al. Mobile application for evaluation of feet in people with diabetes mellitus. Acta Paul Enferm [Internet]. 2017 [cited 2018 Sep 13];30(6):607-13. Available from: http://www.scielo.br/pdf/ape/v30n6/ en_0103-2100-ape-30-06-0607.pdf 